\title{
Influence of the Boriding Process on the Properties and the Structure of S265 Steel and X6CrNiTi18-10 Steel
}

David Bricín, Antonín Křriž

Department of Material Science and Technology, Faculty of Mechanical Engineering, University of West Bohemia in Pilsen. Univerzitní 8, 30100 Plzen. Czech Republic. E-mail: bridca@kmm.zcu.cz, kriz@kmm.zcu.cz

This investigation studied the changes in the microstructure of steels S265 and X6CrNiTi18-10 as a result of their chemical-thermal treatment by boriding. The steels were borided in Durborid boriding powder at $900{ }^{\circ} \mathrm{C}$. During this process, surface layers of Fe-B borides formed in both steels. The layers differed in their morphologies and compositions due to the different degrees of alloying of the matrix of the steels by the additive elements. The Fe-B layers showed high adhesive and cohesive resistance in both steels. Due to changes in the microstructure of the S265 steel, and especially due to significant coarsening of the original grain of its matrix, its resistance to tribological abrasion after boriding decreased. The opposite effect was observed for X6CrNiTi18-10 steel. As a result of boriding, both steels changed their corrosion resistance.

Keywords: S265, X6CrNiTi18-10, Boriding, Corrosion Resistance, Wear

\section{Introduction}

Boriding is a chemical-thermal treatment of materials in which the surface of the material interacts with boron to form hard abrasion-resistant layers. Iron alloys, especially steel, were the first materials to be treated in this way [1]. The oldest technology used for this purpose was boriding using a powder backfill. Since then, a large number of alternative boriding techniques have been developed using gases, liquids, or techniques based on physical principles of mass transfer $[1,2]$. However, boriding using powder is still one of the most common techniques, mainly due to the economic aspect and technological simplicity of the process. [1, 2]. The boride layers formed in this process show high resistance to abrasion, high thermal stability, and resistance to corrosion and oxidation. One of the main advantages of boride layers is the fact that they retain their hardness even at high temperatures, up to $1000^{\circ} \mathrm{C}$. $[2,3]$.

The boriding process using the powder backfill method usually takes place at temperatures of 850$1000{ }^{\circ} \mathrm{C}$ for one or more hours, depending on the required thickness of the layer formed. [1, 2, 4].

The layer can be formed by either a single-phase
$\mathrm{Fe}_{2} \mathrm{~B}$ layer or a two-phase $\mathrm{Fe}_{2} \mathrm{~B}$ layer together with a layer of $\mathrm{FeB}$, which is formed above it [2, 4]. From the point of view of the application, the formation of a $\mathrm{Fe}_{2} \mathrm{~B}$ layer is preferred to the more brittle $\mathrm{FeB}$ layer. In addition, $\mathrm{FeB}$ and $\mathrm{Fe}_{2} \mathrm{~B}$ phases have different coefficients of thermal expansion, which can lead to the formation of cracks in the layer during thermal stressing of the component which subsequently leads to damaging it. $[4,5]$.

The aim of this case study was to verify whether it is possible to increase the useful properties of two types of structural steels, S265 and X6CrNiTi18-10, by boriding. These steels are used, for example, for the production of parts that transport loose, gaseous or liquid media. The aim of the study was to verify how the boriding process affects the microstructure, surface properties, and corrosion resistance of the steels.

\section{Experimental material and procedures}

\subsection{Experimental material}

- Two types of structural steels were selected as experimental materials, S265 and X6CrNiTi18-10. These steels differ in chemical composition, see Table 1.

Tab. 1 Comparison of the chemical composition of steels used in the experiment

\begin{tabular}{|c|c|c|c|c|c|c|c|c|}
\hline & $\mathrm{C}$ & $\mathrm{Si}$ & $\mathrm{S}$ & $\mathrm{P}$ & $\mathrm{Mn}$ & $\mathrm{Cr}$ & $\mathrm{Ni}$ & $\mathrm{Ti}$ \\
\hline S265 & $\leq 0.2$ & $\leq 0.4$ & $\leq 0.025$ & $\leq 0.03$ & $\leq 1.4$ & - & - & - \\
\hline X6CrNiTi18-10 & $\leq 0.08$ & $\leq 1.0$ & $\leq 0.015$ & $\leq 0.045$ & $\leq 2.0$ & $17-19$ & $9-12$ & $\leq 0.7$ \\
\hline
\end{tabular}


S265 steel is carbon steel with a structure of ferrite and pearlite. In contrast, X6CrNiTi18-10 steel is alloyed with a high proportion of $\mathrm{Cr}$ and $\mathrm{Ni}$, and its structure is formed by austenite.

\subsection{Parameters of the boriding process}

Chemical heat treatment of samples made from the steels was performed in Durborid boron powder. This powder, together with the samples, was hermetically sealed in a steel box, which was then placed in a chamber furnace preheated to $900^{\circ} \mathrm{C}$. The samples were processed at this temperature for four hours. After this time, in one case the box with the samples was removed from the oven to allow it to cool in air, and in the other case, the box was left to cool in the oven.

\subsection{Evaluation methods}

Samples of S265 and X6CrNiTi18-10 were divided into two groups. The surfaces of both groups of samples were ground and polished first by using a semiautomatic Tegramin-20 grinder. Then, half the samples were subjected to chemical-thermal treatment by boriding. Subsequently, the borided samples were analysed for the cohesive-adhesive behaviour of the formed layer towards the substrate. This analysis was performed using the Mercedes test. In this test, a Rockwell indenter with a force of $1500 \mathrm{~N}$ was pressed into the surface of the samples. Results were then evaluated using the table below, see Fig. 1, where the best adhesive resistance corresponds to A1 and the best cohesive wear to K1 [6].
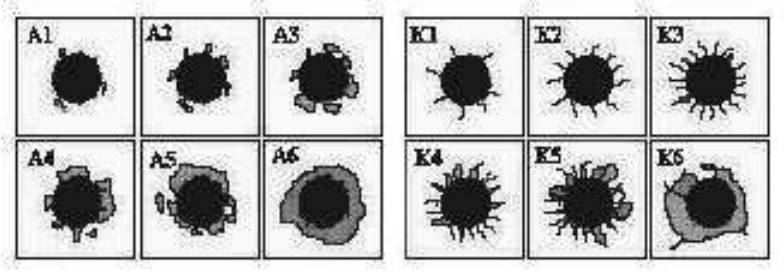

Fig. 1 Overview of infractions that may occur after the Mercedes test. The table is divided into adhesive (A1-AG) and cohesive (K1-K6) thin-film failure [6].

After the analysis of the cohesive-adhesive behaviour of the layer towards the substrate, the samples were analysed for changes in tribological abrasion resistance using the Ball on Disk method. In this analysis, the resistance of the surface of the sample to abrasive and adhesive wear is determined. In this analysis, an indenter was pressed into the rotating surface of the sample with a force of $20 \mathrm{~N}$. The sample speed was set at $154 \mathrm{rpm}$. A $6 \mathrm{~mm}$ diameter corundum ball was used as the indenter. The number of cycle repetitions was set to 5,000 cycles. The tribological trace was then measured using an optical stereomicroscope at four different locations, at $32 \mathrm{x}$ magnification. The aim was to determine the material removal $\mathrm{V}$, see equation 1 , and the wear coefficient, see equation 2 . These calculations are based on ASTM G99 [7].

$$
\mathbf{W}=\frac{\mathbf{V}}{\mathbf{L} \cdot \mathbf{s}}\left[\frac{\mathbf{m m}^{3}}{\mathbf{N} \cdot \mathbf{m}}\right]
$$$$
V=\frac{\pi(\text { wear track radius,mm })\left(\text { track width, } \mathrm{mm}^{3}\right)}{6(\text { sphere radius }, \mathrm{mm})}\left[\mathrm{mm}^{3}\right]
$$

Where:

V... Worn volume (removal of material) $\left[\mathrm{mm}^{3}\right]$

L... Normal load (Fn) [N]

s... The total length of the path of movement of the indenter $[\mathrm{m}]$

After the analysis of the surface condition, the samples were subjected to metallographic analysis which consisted of the analysis of the structure of the boride layer, analysis of the change in the microstructure of the samples, and analysis of the micro-hardness of the samples before and after the boriding process. A 3\% solution of Nital etchant was used to reveal the structure of the S265 steel samples. An etchant composed of $45 \mathrm{ml}$ of glycerol, $15 \mathrm{ml}$ of nitric acid, and 30 $\mathrm{ml}$ of hydrochloric acid was used to reveal the structure of the X6CrNiTi18-10 steel samples. Subsequent analysis was performed using a Philips XL30ESEM scanning electron microscope, a Nikon SM2800 light stereo microscope, and a Carl Zeiss Observer Z1m light microscope. The hardness of the sample matrix and the boride layers was measured using a semi-automatic DuraScan hardness tester. The grain size of the sample matrix was determined by the intersection method [8].

The above experiments were supplemented by an analysis of the corrosion resistance of the samples before and after boriding. This analysis consisted of a fog test in which the samples were left in a VLM CCT climate chamber in a $100 \%$ humidity environment, at a temperature of $40^{\circ} \mathrm{C}$ for 72 hours.

\section{Experimental results and discussion}

\subsection{Changes to the surface structure and the matrix}

Fig. 2 shows the surface structures of the S265 and X6CrNiTi18-10 steel samples. The figures show the effect of the degree of alloying on the layer structure. The S265 steel layer has a typical tooth-like texture. According to the Fe-B binary diagram, this layer can be formed by either one $\mathrm{Fe}_{2} \mathrm{~B}$ structural phase or $\mathrm{Fe}_{2} \mathrm{~B}$ together with $\mathrm{FeB}$. In this case, it was possible to form a single-phase layer on the surface of the samples composed only of the $\mathrm{Fe}_{2} \mathrm{~B}$ boride phase, which is tougher and more malleable than a layer formed by the $\mathrm{FeB}$ phase. The FeB boride layer is harder and would be above the $\mathrm{Fe}_{2} \mathrm{~B}$ layer. Because this layer is slightly harder and has a different chemical composition, it 
would be visible due to the different etching of it, which did not happen in this case. The texture of the boride layer formed on X6CrNiTi18-10 steel did not have a typical toothed structure, but was separated from the sample substrate by a sharp border, see Fig. 2. Below the boride layer, a diffusion zone was visible, extending to a depth of about $50 \mu \mathrm{m}$. The figure also

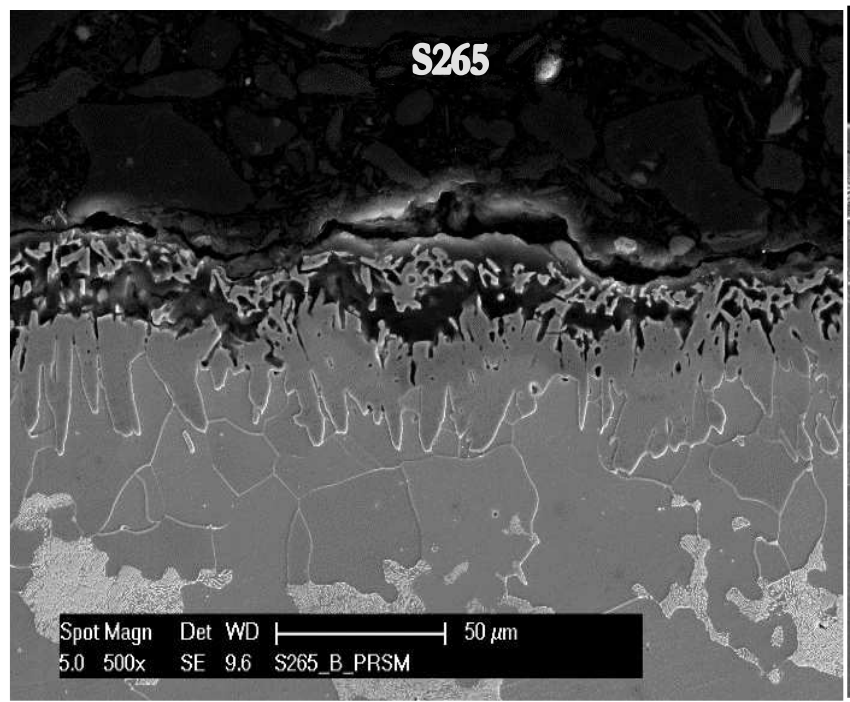

shows the method of layer growth, in which new particles are first formed along the boundaries of austenitic grains and later in their volume. In addition to the texture, the layers created differed in their uniformity and thickness. The fact that the layers consisted of only one phase was indirectly confirmed by the measurement of the hardness HV0.025, see Table 2.

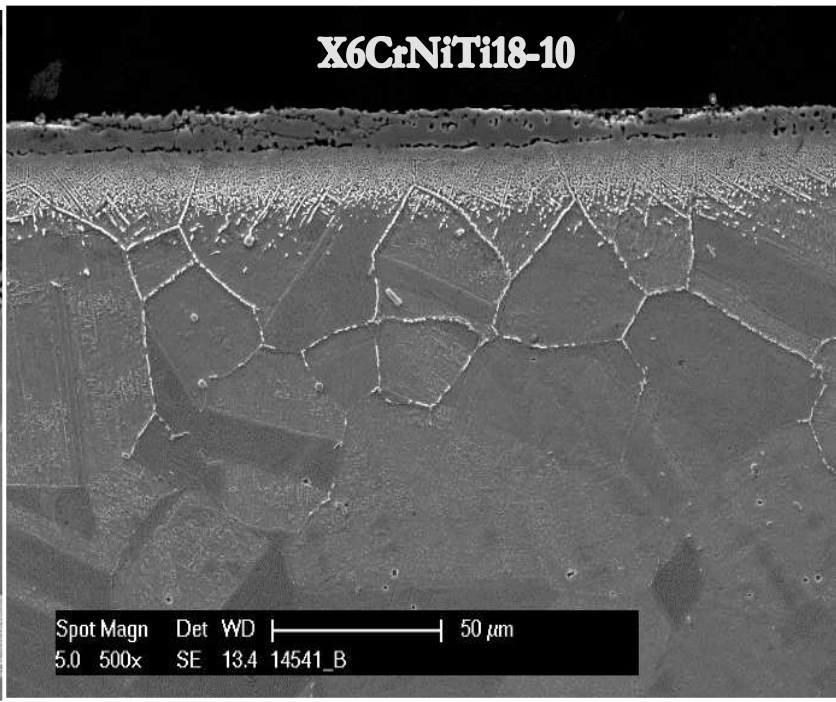

Fig. 2- The boride layer structure of steels S265 and X6CrNiTi18-10, magnified 500x

Tab. 2 Comparison of changes in grain size, HV hardness and thickness of the formed layer in steel samples S265 and X6CrNiTi18-10 before and after boriding.

\begin{tabular}{|l|l|l|l|l|}
\hline & S265 & S265 (borided) & X6CrNiTi18-10 & $\begin{array}{l}\text { X6CrNiTi18-10 } \\
\text { (borided) }\end{array}$ \\
\hline Grain size $(\mu \mathrm{m})$ & $20 \pm 2.9$ & $39 \pm 8$ & $46 \pm 8.5$ & $50 \pm 8.9$ \\
\hline Matrix hardness $(\mathrm{HV} 0.1)$ & $186 \pm 11.6$ & $141 \pm 10.4$ & $198 \pm 17.7$ & $203 \pm 12.2$ \\
\hline Layer thickness $(\mu \mathrm{m})$ & - & $29 \pm 12.3$ & - & $9.7 \pm 1.0$ \\
\hline Layer hardness $(\mathrm{HV} 0.025)$ & - & $1572 \pm 329$ & - & $1507 \pm 164$ \\
\hline
\end{tabular}

When evaluating the structure of the analysed samples, the effect of alloying on the growth stability of the original grains of the steel matrices became apparent. In the case of S265 steel, the grains in the matrix of the material significantly coarsened at the surface of the sample to about twice the size and larger, see Table 2 and figures 3 and 4 . The effect of the cooling rate from the boriding process temperature is also evident in the steel structure. During rapid cooling, see Fig. 3, there was a significant coarsening of the structure in the sample surface to a depth of about $1.2 \mathrm{~mm}$ and the formation of a Widmannstätten structure. This proeutectoid structure is formed at cooling rates which are too high. In these cases, the diffusion of the elements is not complete, especially in the coarse-grained structure of the materials, and thus supersaturated areas are formed which facilitate the formation of this phase of $\alpha$-ferrite and its growth (needle formation) into the volume of the material, which is less energy- efficient than the formation of the $\alpha$-phase along the boundaries of the original austenite grains [9-11]. When the cooling rate is reduced, the diffusion of the elements is complete, i.e. the concentration differences are gradually compensated and thus the formation of equilibrium structures of ferrite and pearlite is promoted, see Fig. 4. Although the final structure is very coarse, it no longer contains the Widmannstätten structures (see Fig. 3), which impairs some of the mechanical properties of steels, especially their fracture toughness [12]. Because of the coarsening of the matrix of the material, there was a significant reduction in its hardness by about $24 \%$, see Table 2 .

In the case of X6CrNiTi18-10 steel, the coarsening of the structure was not so significant and was around $8 \%$, regardless of the cooling rate from the chemicalthermal processing temperature of the steel, see Table 2 and Fig. 5. 


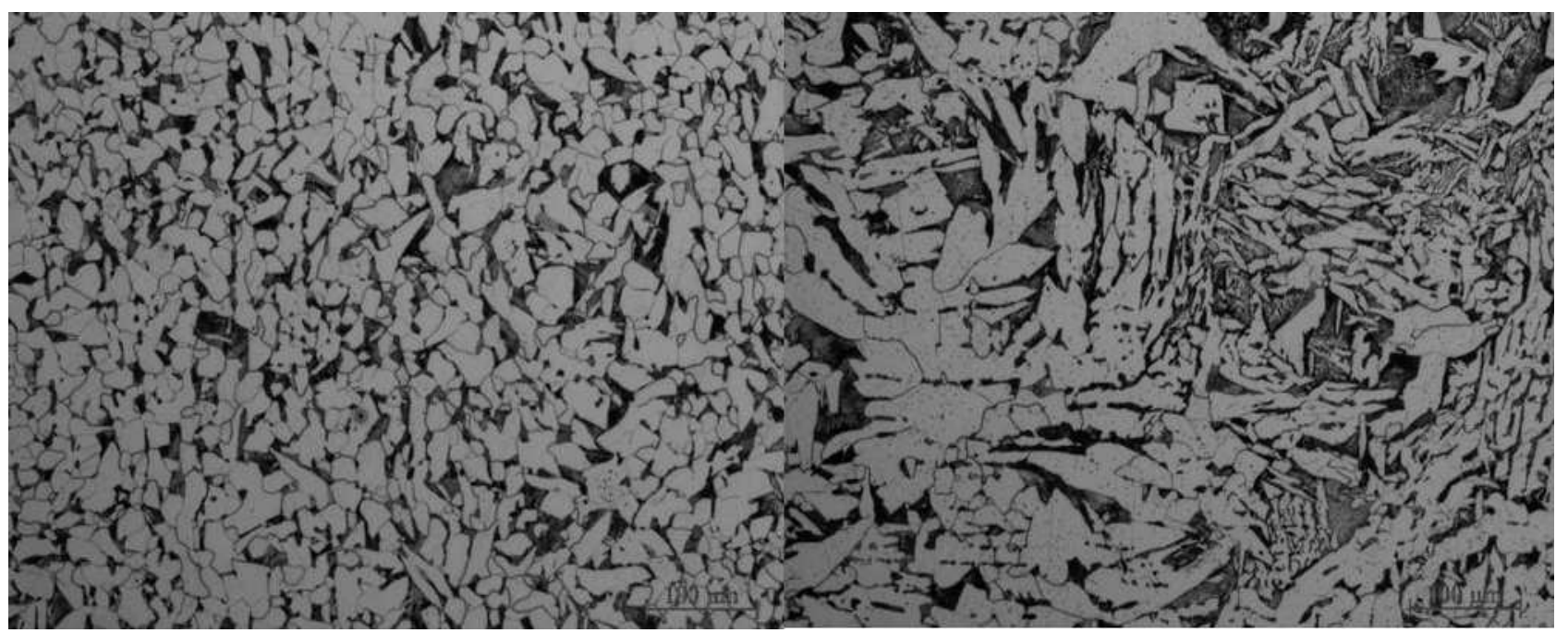

Fig. 3 Change in the microstructure of S265 steel samples. The left part of the figure shows the original structure of the sample. The right part of the figure shows the structure of the sample after the boriding process with cooling in air, magnified 100x

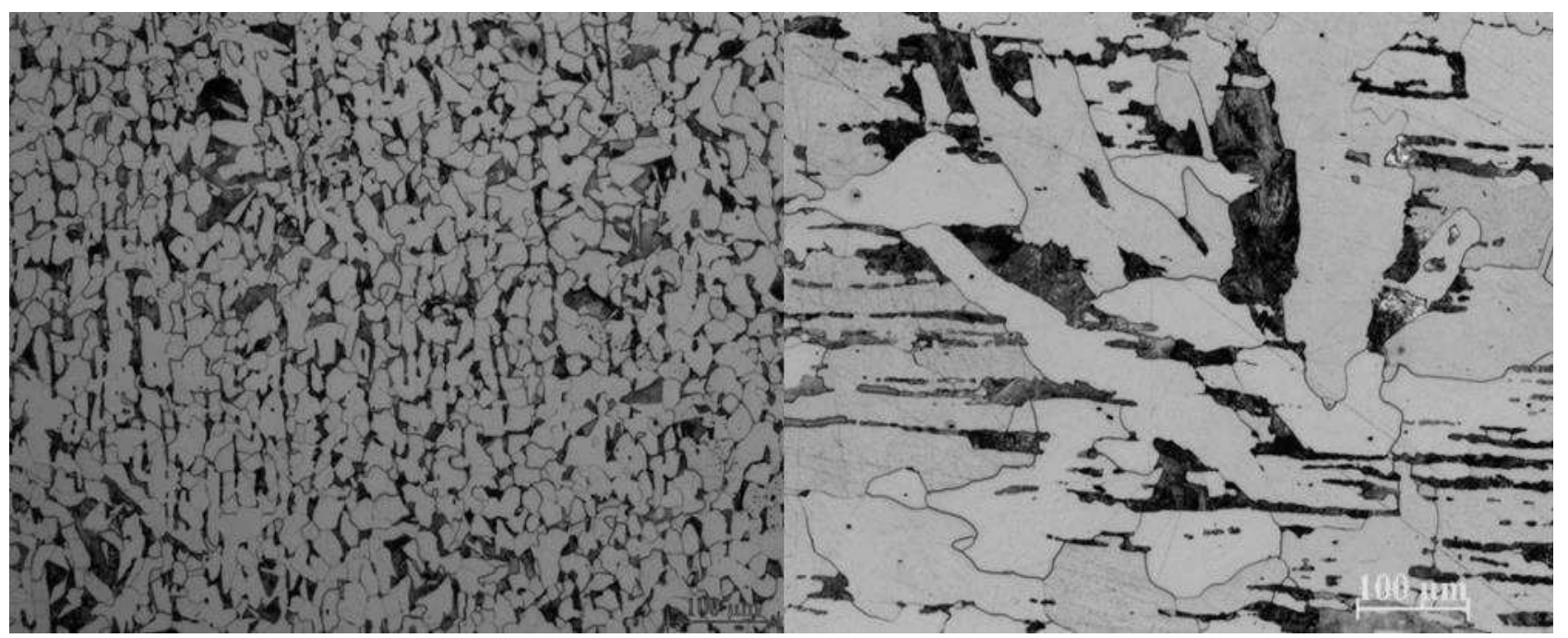

Fig. 4 Change in the microstructure of $S 265$ steel samples. The left part of the image shows the original structure of the sample, magnified 100x. The right part of the figure shows the structure of the sample after the boriding process with gradual cooling in the furnace, magnified $50 x$

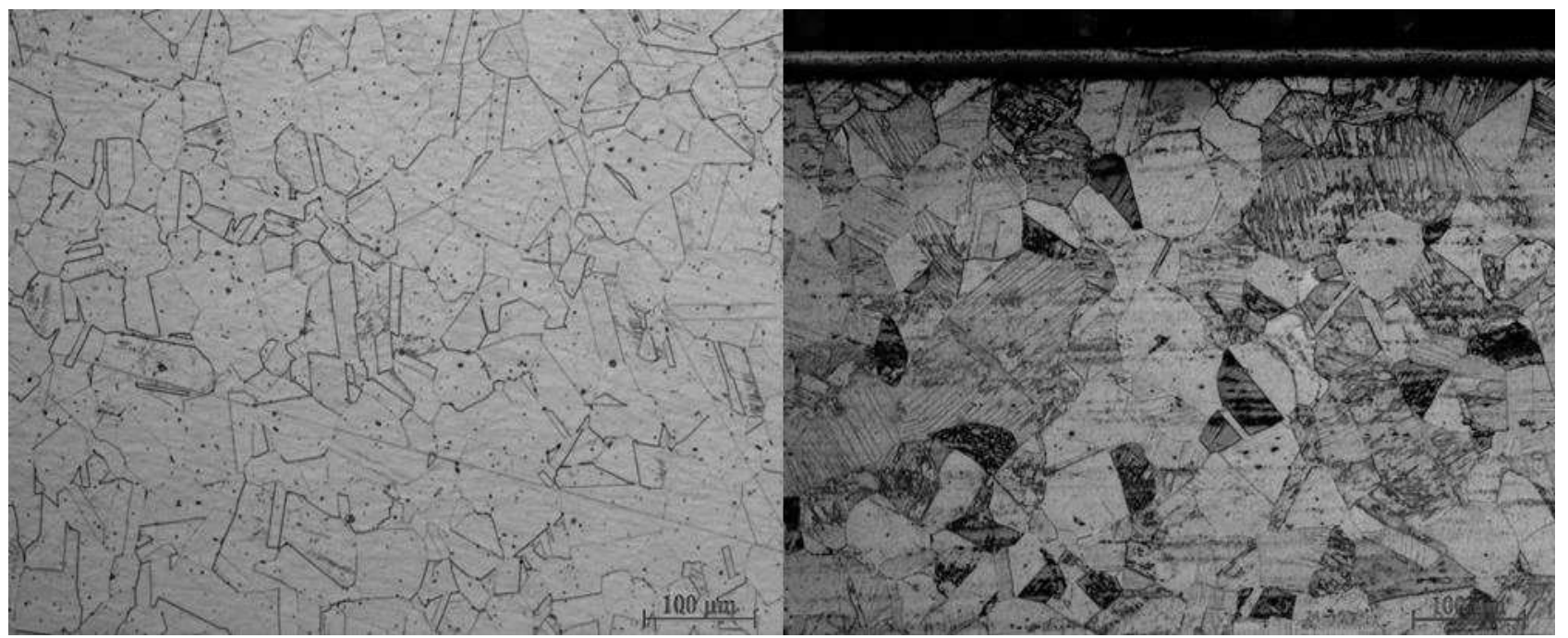

Fig. 5 Change in the microstructure of X6CrNiTi18-10 steel samples. The left part of the figure shows the original structure of the sample. The right part of the picture shows the structure of the sample after the boriding process with cooling in air, magnified 100x 
The strength of the structure of this steel is associated with its alloying with elements of nickel, chromium, and titanium. Nickel as an austenite-forming element increases the strength of the solid solution and its temperature stability. Titanium and chromium, on the other hand, form different types of carbides, see Fig. 6. These carbides dissolve into a solid solution at high temperatures and sufficient time, thereby increasing its temperature stability and then, as primary carbides, form natural barriers to grain movement, reducing their growth rate.

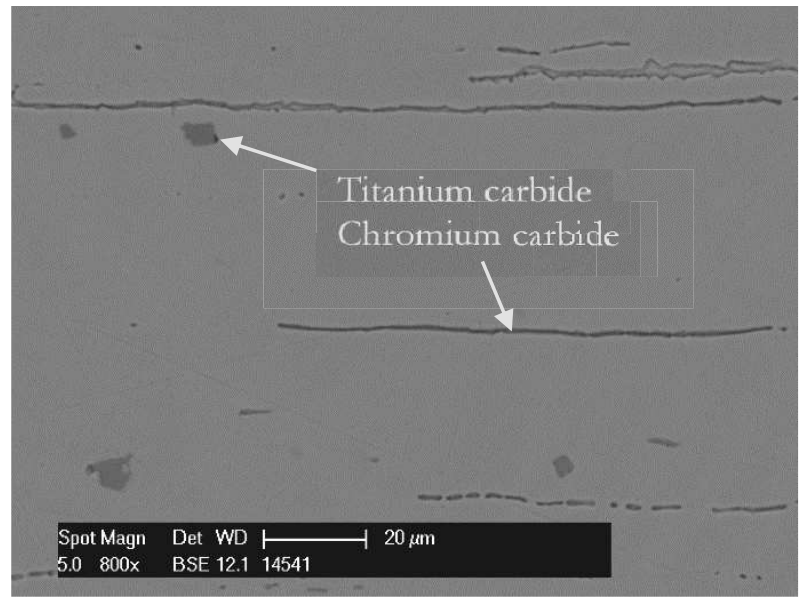

Fig. 6 Carbide structure. To determine the type of carbides, an EDX analysis of their chemical composition was performed, magnified 800x.

\subsection{Tribological properties and Mercedes test}

The microstructure of both steels greatly affected the ability of the material to resist abrasive wear. The difference in the calculated wear coefficient is illustrated in Figure 7. The graph in this figure shows that due to the coarsening of the S265 steel grain structure and the presence of the Widmannstätten structures, its abrasion resistance deteriorated significantly by more than $600 \%$. The higher wear rate was then probably further associated with the unevenness of this layer. Although the layer was formed on the entire surface of the sample, because it was formed by a tooth-like texture, the matrix substrate was firstly exposed in places where this layer is thinner. This, together with the fact that the matrix near the layer was partly formed by the Widmannstätten structures, which is brittle, led to shocks when moving the indenter, which caused the adhesive layer failure, thus increasing the surface wear value of this steel.

In the case of X6CrNiTi18-10 steel, the chemicalthermal treatment had the opposite effect, and its abrasion resistance increased by about $900 \%$. This fact was associated with the formation of a significant diffusion zone under the boride layer, see Fig. 2. This intermediate layer was harder than the matrix due to the formation of borides, namely $899 \pm 237 \mathrm{HV} 0.025$. Below this diffusion zone, a similar hardness was measured for the matrix as for the samples that were not borided.

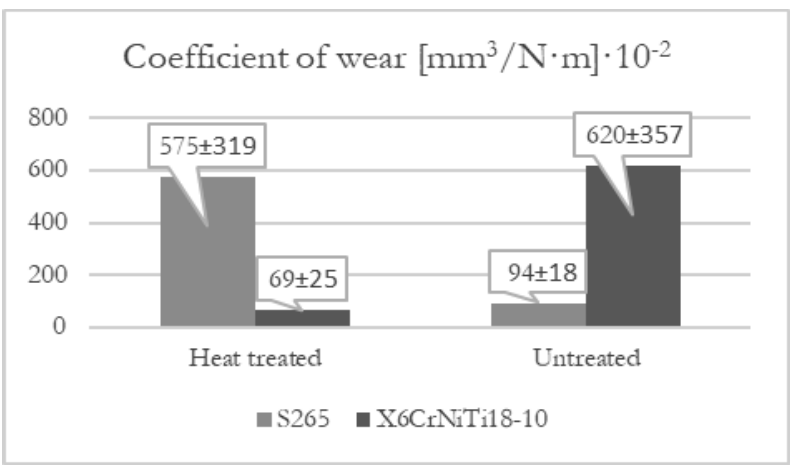

Fig. 7 Comparison of the resistance of the substrates of the samples to tribological abrasion before and after boriding

The Mercedes test showed a high adhesive and cohesive resistance of the layer to the substrate, see Fig. 8. This indicates a high resistance of these layers to failure, regardless of whether these layers have a toothed texture or are separated from their surroundings by a sharp interface as in the case of X6CrNiTi1810 steel.

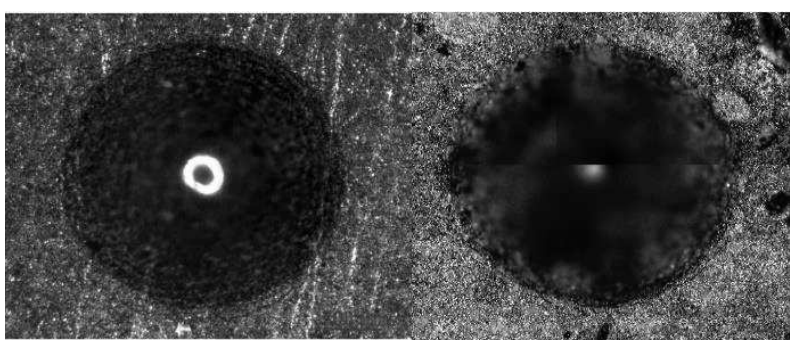

Fig. 8 Comparison of the resistance of layers to cohesive adhesive failure. Left - impact crater of steel S265. Right - impact crater of steel X6CrNiTi18-10, magnified 100x

\subsection{Corrosion resistance}

The boriding process changed the corrosion resistance of both materials. There was significant corrosion on the surface of the samples after the boriding process during the fog test, see Fig. 9. In contrast, the corrosion was significantly less after 72 hours in the fog chamber. The reason for the more pronounced oxidation of the surface is the fact that the boride layer has a lower corrosion resistance, which is caused by its phase composition. Metallographic analysis was performed on the steels to assess the effect of boriding on their corrosion resistance, see Figures 10 and 11.

In the case of S265 steel without boriding, there was local corrosion on its surface, see Fig. 10. It is evident from the images that the corrosion of the surface first proceeded in the area of the ferrite grain boundaries and then spread to their volume. The maximum depth of this attack was around $25 \mu \mathrm{m}$. In the borided samples, corrosion occurred over the entire area. Cracking and local distuption of the Fe2B layer due to corrosion were recorded. The maximum depth of corrosion in localised areas reached values of about 40 $\mu \mathrm{m}$. 


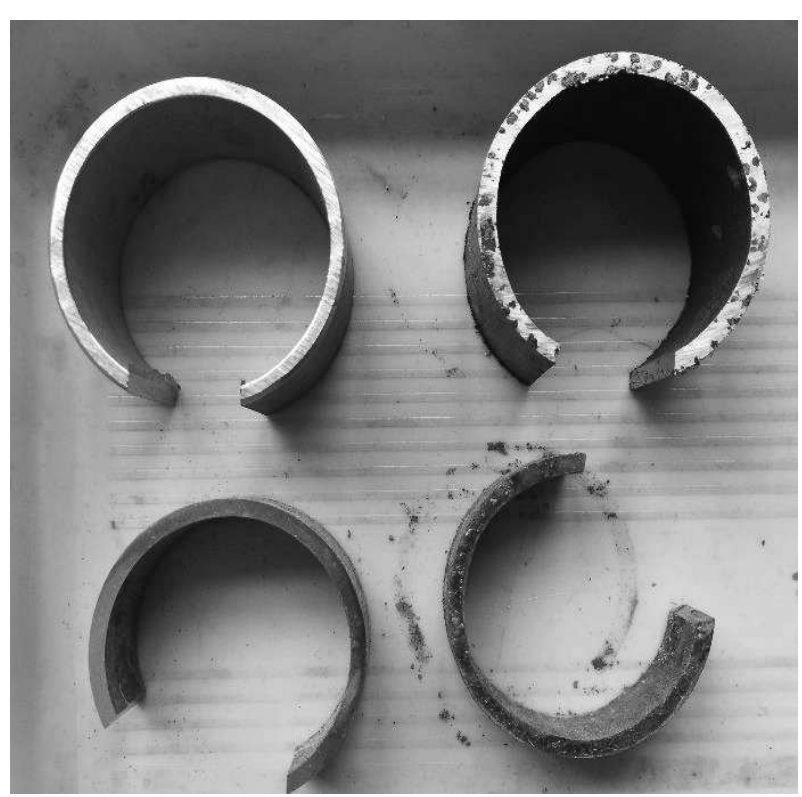

Fig. 9 Comparison of corrosion on the surface of samples, before and after their treatment by boriding, in an environment of $100 \%$ bumidity. The samples at the top are samples before chemical heat treatment. The samples below are samples after chemical heat treatment by boriding. The samples on the left are samples made of X6CrNiTi18-10 steel, the samples on the right are samples made of $S 265$ steel
No corrosion of the substrate material was observed in the steel. However, its grain structure significantly coarsened during the boriding process. The coarsening of the grain structure further affects the rate at which the steel matrix corrodes [13-15]. Due to the coarsening of the structure of the material, the density of the grain boundaries in its surface layer is reduced. This then results in a reduction in the chemical activity at the surface and this in turn leads to a reduction in the number of activation sites where corrosion of the surface can occur. As a result, further corrosion can be slower than in materials without boriding. However, due to the greater roughness of the structure, selective corrosion of the individual structural phases may occur more easily, or it may be easier to form an uneven passivation layer which could slow down the rate of corrosion attack on the surface of the material.

In the case of X6CrNiTi18-10 steel, no corrosion products formed on the surface of the samples without chemical-thermal treatment by boriding. In contrast, local violation of the borided layer to the boundary of the diffusion zone were observed in the samples that were processed, see Fig. 11. The greatest depth of corrosion attack locally corresponded to a value of about $10 \mu \mathrm{m}$.

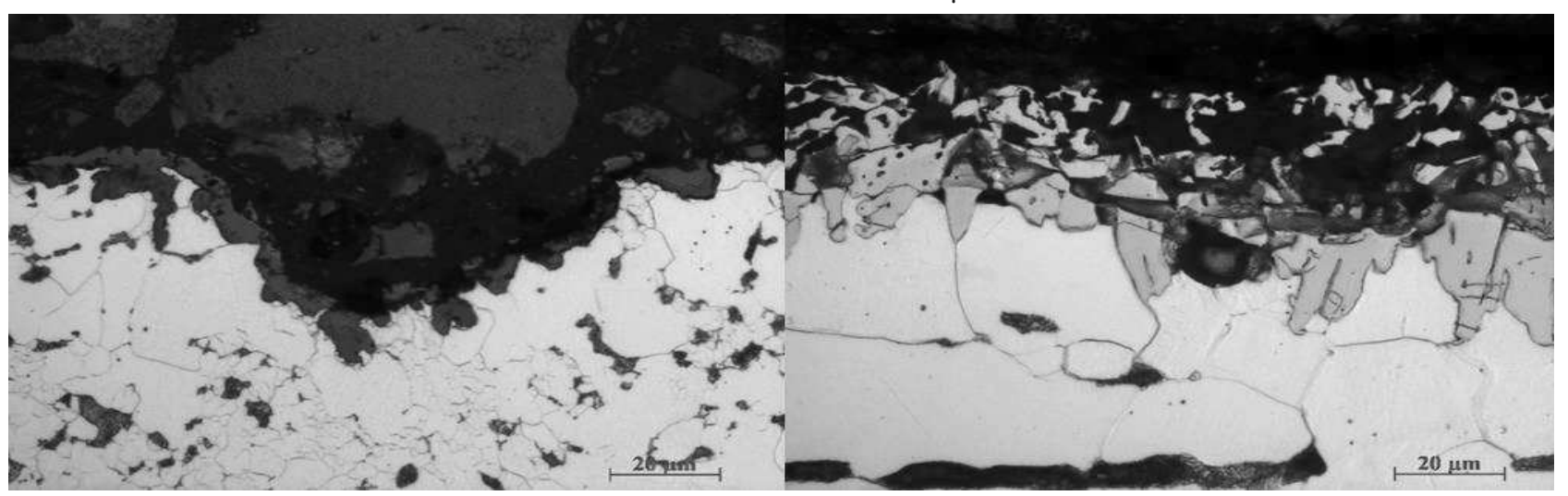

Fig. 10 Comparison of corrosion damage on samples of 5265 steel. The left side of the figure shows the corrosion products on the surface of the steel before boriding. The right side of the picture shows corrosion products on the surface of steel after processing, magnified $500 x$

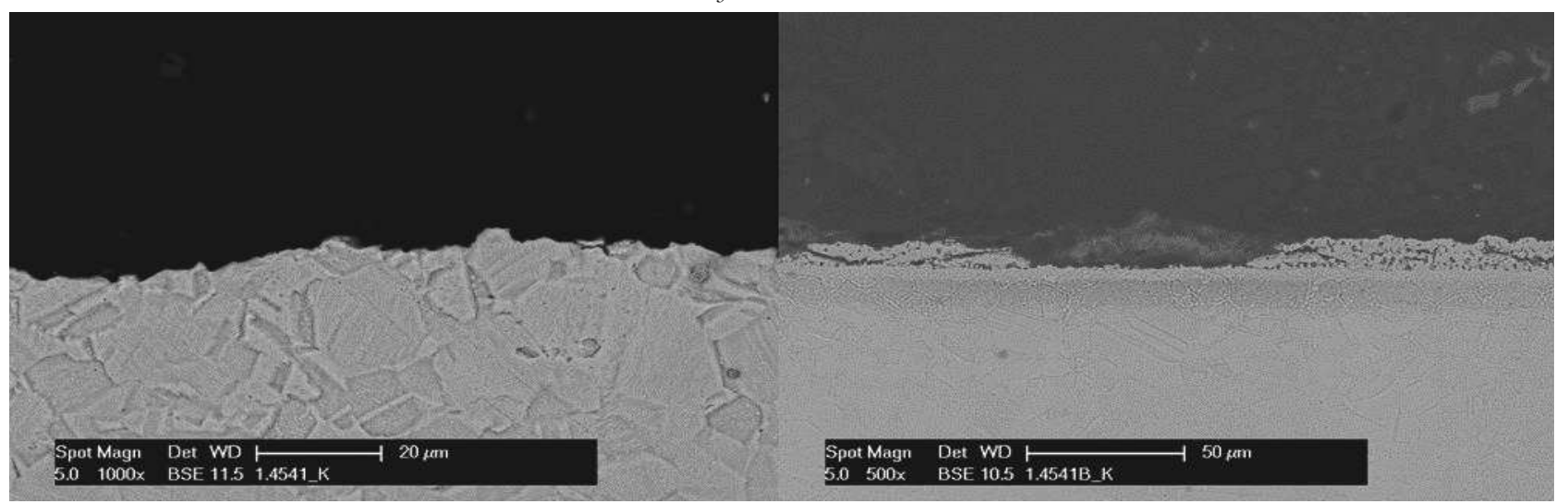

Fig. 11 Comparison of corrosion damage on X6CrNiTi18-10 steel samples. The left side of the picture shows the corrosion products on the surface of the steel before boriding, magnified 1000x. The right side of the picture shows corrosion products on the surface of steel after processing, magnified $500 x$. 


\section{Conclusion}

In the experiment, the changes caused by the boriding process in steel S265 and steel X6CrNiTi1810 were analysed. The results can be summarized as follows:

- A single-phase layer of $\mathrm{Fe}_{2} \mathrm{~B}$ borides was formed on the steels during the process.

- The layers had excellent adhesion and cohesion to the substrates, and no peeling of the layers or the presence of a higher number of cracks was recorded in the vicinity of the impact craters.

- The thickness and texture of the layers varied in the samples depending on the degree of alloying. In the case of carbon steel S265, the texture of the layer was toothed, in contrast, in the case of alloy steel X6CrNiTi18-10, the layer was separated from the matrix by a sharp interface. The layer thickness was about 3.2 times higher in S265 steel $(29 \pm 12.3 \mu \mathrm{m}$. However, unlike X6CrNiTi18-10 steel, its texture was not uniform..

- In the structure of S265 steel, during its process of chemical heat treatment, its original grain size grew significantly by about $95 \%$ and more. During the rapid cooling from the boriding temperature, in addition to the coarsening of the grain structure of S265 steel, the so-called Widmannstätten structure was formed.

- The grain structure of X6CrNiTi18-10 steel did not significantly coarsen because the alloying elements stabilized the solid solution and the chromium and titanium carbides limited the growth of the original austenite grains.

- For S265 steels, when evaluating the resistance of the substrate to abrasive wear using the Ball on disk method, its resistance deteriorated significantly. The opposite effect was observed for X6CrNiTi18-10 steels.

- In terms of corrosion resistance, the samples after the boriding process were damaged by corrosion to a greater depth and over a larger surface area than the samples which were not treated by this process. Despite the good corrosion resistance of these layers, the corrosion resistance of the surface of the treated samples deteriorated.

\section{Acknowledgement}

This article was made possible by the funding for the SGS-2018-051 project "Application of new treatment and test procedures to surfaces and bulk materials for improved usability of assemblies and work tools in industry".

\section{References}

[1] KULKA, M. (2019). Current Trends In Boriding. New York: Springer. ISBN 978-3-030-06781-6

[2] TÜRKMEN, İ., YALAMAÇ, E., KEDDAM, M. (2019). Investigation of tribological behaviour and diffusion model of Fe2B layer formed by pack-boriding on SAE 1020 steel. Surface and Coatings Technology, 377, p.124888. DOI: 10.1016/j.surfcoat.2019.08.017

[3] CIMENOGLU, H., ATAR, E., MOTALLEBZADEH, A. (2014). High temperature tribological behaviour of borided surfaces based on the phase structure of the boride layer. Wear, 309(1-2), pp.152-158. DOI: 10.1016/j.wear.2013.10.012

[4] GERSTENBERGER, J. (2010). Vytváření tvrdých a otěruvzdorných povrchů pomocí boridování. MM Primyslové spectrum, Vol. 3, pp. 28

[5] JOSHI, A., HOSMANI, S. (2014). Pack-Boronizing of AISI 4140 Steel: Boronizing Mechanism and the Role of Container Design. Materials and Manufacturing Processes, 29(9), pp.10621072. DOI: $10.1080 / 10426914.2014 .921705$

[6] KŘÍŽ, A. (1998). Vlastnosti řezných nástrojů s tenkými vrstvami TiN, ZrN, Dissertation, University of West Bohemia in Pilsen

[7] ASTM G99-17. (2017). Standard Test Method for Wear Testing with a Pin-on-Disk Apparatus. ASTM International, West Conshohocken, PA. www.astm.org

[8] ISO 643. (2003). Steels - Micrographic determination of the apparent grain size. Available from:

https://www.iso.org/obp/ui/\#iso:std:iso:643: ed-4:v2:en

[9] SKÁlOVÁ, J., KOUTKSÝ, J., MOTYČKA, V.(2000). Nauka o materiálech. Západočeská univerzita v Plzni. ISBN 80-7082-677-0

[10] LEONT'EV, B., OSENKO, A. (1973). Formation of Widmannstatten structure in carbon 
steels. Metal Science and Heat Treatment, 15(6), pp.511-512. DOI: 10.1007/BF01153279

[11] TODOROV, R., KHRISTOV, K. (2004). Widmanstatten Structure of Carbon Steels. Metal Science and Heat Treatment, 46(1/2), pp.49-53. DOI: 10.1023/B:MSAT.0000029601.58461.bd

[12] KOVAL'CHUK, G., GEICHENKO, V., YARMOSH, V. AND PODOBEDOVA, L. (1979). Effect of Widmanstatten ferrite on some properties of hypoeutectoid steel. Metal Science and Heat Treatment, 21(2), pp.114-117. DOI: $10.1007 /$ BF00801483

[13] SOLEIMANI, M., MIRZADEH, H. AND DEHGHANIAN, C. (2020). Effect of grain size on the corrosion resistance of low carbon steel. Materials Research Express, 7(1), p.016522. DOI: $10.1088 / 2053-1591 /$ ab62fa

[14] Fu, X., Ji, Y., Cheng, X., Dong, C., Fan, Y. and $\mathrm{Li}, \mathrm{X}$. (2020). Effect of grain size and its uniformity on corrosion resistance of rolled $316 \mathrm{~L}$ stainless steel by EBSD and TEM. Materials Today Communications, 25, p.101429. DOI: 10.1016/j.mtcomm.2020.101429

[15] GOLLAPUDI, S. (2012). Grain size distribution effects on the corrosion behaviour of materials. Corrosion Science, 62, pp.90-94. DOI: /10.1016/j.corsci.2012.04.040"

[16] KUČEROVÁ, L., JANDOVÁ, A. and RUBEŠOVÁ, K. Microstructure Analysis and Mechanical Properties of Low Alloyed Steel with Retained Austenite Obtained by Heat Treatment. Manufacturing Technology. 2019;19(2):243-247. doi: 10.21062/ujep/277.2019/a/12132489/MT/19/2/243.

[17] DOBROCKÝ, D., STUDENÝ, Z., POKORNÝ, Z., JOSKA, Z. and FALTEJSEK P. Assessment of Surface Structure of Machined Surfaces. Manufacturing Technology. 2019;19(4):563-572. doi: 10.21062/ujep/335.2019/a/12132489/MT/19/4/563. 